\title{
Retrospective study of allometric relationship between heart rate, electrocardiographic parameters and bodyweight in dogs
}

[Estudo retrospectivo da relação alométrica entre frequência cardíaca, parâmetros eletrocardiográficos e peso corporal em cães]

\author{
A.S.C. Aleixo, A. Alfonso, M.G. Fillippi, \\ S.B. Chiacchio, M.L.G. Lourenço*
}

Escola de veterinária - Universidade Estadual Paulista - Botucatu, SP

\begin{abstract}
The allometric relationship between bodyweight (BW) and heart rate (HR) has been described as inversely proportional in domestic species, but that has been refuted. The relationship between HR and electrocardiographic variables is described in literature. However, studies about the variation and influence of factors on the hemodynamic and electrocardiographic parameters in dogs are not abundant. As the metabolic rate is defined as the production and dissipation of heat by the body surface area (BSA) in $\mathrm{m}^{2}$, it is essential to define that relationship. A retrospective study was conducted to analyze the correlation between HR, ECG parameters and BW in dogs. One thousand electrocardiographic tracings were analyzed in addition to the ECG parameters and clinical data such as gender, age and bodyweight. The determination of BSA was performed as follows: BSA $\left(\mathrm{m}^{2}\right)=\left(10.1 \mathrm{x}^{2}\right.$ bodyweight $\left.{ }^{0.67}\right) \times 10^{-4}$. When the unified groups were analyzed, there was a negative but weak correlation $(r=-0.14, \mathrm{P}<0.0001)$ between bodyweight and HR. There were differences between weight groups regarding electrocardiographic variables. There is no allometric relationship between BW and HR in dogs. Weight was associated with changes in ECG variables.
\end{abstract}

Keywords: body surface area, weight, allometric, electrocardiogram

\section{RESUMO}

A relação alométrica entre peso corporal $(P C)$ e frequência cardíaca $(F C)$ foi descrita como inversamente proporcional em animais domésticos, mas isso tem sido refutado. A relação entre $F C e$ variáveis eletrocardiográficas é descrita na literatura. No entanto, estudos sobre a variação e a influência de fatores nos parâmetros hemodinâmicos e eletrocardiográficos em cães não são abundantes. A taxa metabólica é definida como a produção e dissipação de calor pela área de superfície corporal (ASC), de modo que é essencial definir essa relação. Foi realizado um estudo retrospectivo para analisar a correlação entre $F C$, parâmetros eletrocardiográficos (ECG) e peso corporal em cães. Foram analisados mil traçados eletrocardiográficos, além dos parâmetros de ECG e dados clínicos, como gênero, idade e peso corporal. A determinação da ASC foi realizada da seguinte forma: $A S C\left(\mathrm{~m}^{2}\right)=$ $\left(10,1 x\right.$ peso corporal $\left.{ }^{0,67}\right) \times 10^{-4}$. Quando os grupos unificados foram analisados, houve uma correlação negativa, porém fraca $(r=-0,14, P<0,0001)$ entre $P C$ e FC. Houve diferenças entre os grupos de peso em relação às variáveis eletrocardiográficas. Não há relação alométrica entre PC e FC em cães. O peso foi associado a alterações nas variáveis de ECG.

Palavras-chave: área superficial do corpo, peso, alometria, eletrocardiograma

Recebido em 21 de novembro de 2017

Aceito em 19 de março de 2019

*Autor para correspondência (corresponding author)

E-mail: maria-lucia.lourenco@unesp.br 


\section{INTRODUCTION}

The allometric relationship between bodyweight (BW) and heart rate (HR) has been described for years as inversely proportional among species, with HR being higher in species such as small rodents (500-700 beats per minute) and lower in whales ( 20 beats per minute). Based on that principle, the normal range of HR in dogs has been described according to BW (Ferasin et al., 2010)

The relationship between BW and HR in dogs (i.e., small breeds have higher HRs; large breeds have lower HRs) that has been proposed for decades is currently being challenged. That relationship may be a reflection of temperament and the sympathetic autonomic stimulation of the sinus node in small breeds compared with large breeds (Lamb et al., 2010). The autonomic nervous system is defined as the peripheral motor system. It is subdivided into the sympathetic and parasympathetic nervous systems and maintains homeostasis in the body. Heart rate is constantly subjected to autonomic tone fluctuations determined by the activation of adrenergic receptors or sympathetic and parasympathetic inhibition (Reis et al., 1998). The variation of cardiac depolarization intervals, provided by the autonomic influence, can be detected by electrocardiogram for the different distances between the normal intervals of the $\mathrm{R}$ wave (RR intervals or NN) (Paschoal et al., 2006).

In veterinary medicine, although the relationship between HR and electrocardiographic QT and PR intervals is known and described in the literature, studies with the variation and influence of several factors on the hemodynamic and electrocardiographic parameters in healthy dogs are not abundant. That happens due to the difficulty in determining the normal physiological changes and the effects of drugs used in animals (Soloviev et al., 2006). The aim of this study was to investigate the relationship between HR and BW as well the influence of weight on electrocardiographic variables (P wave, QRS complex, T wave).

\section{MATERIAL AND METHODS}

We analyzed 1000 stored electrocardiographic tracings during 2012 and 2013 from the
Veterinary Hospital Cardiology Department, from the School of Veterinary Medicine and Animal Science of São Paulo State University, Botucatu/Brazil. This study was approved by the Ethics Committee on Animal Use (41/2013CEUA). To carry out the study, ECG parameter data and clinical data such as gender, age, and $\mathrm{BW}$ were compiled. The determination of body surface area (BSA) was performed as follows: BSA $\left(\mathrm{m}^{2}\right)=\left(10.1 \times \mathrm{BW}^{0.67}\right) \times 10^{-4}$, as described by Hill and Scott (2004), with BW measured in grams. The inclusion criteria were electrocardiograms of dogs from pre-anesthetic (e.g., for biopsy procedures) or surgical evaluations (e.g., neutering surgeries) that revealed sinus rhythm or respiratory sinus arrhythmia electrocardiographic variables. The exclusion criteria were the presence of any type of arrhythmia, conduction disorders, detection of premature ventricular contractions.

Pearson and Spearman correlation tests were used to test for correlations between HR and BW and between HR and BSA for parametric and non-parametric data, respectively. The MannWhitney test was used for statistical analysis of differences in HR obtained by electrocardiogram and HR obtained by logarithmic equation between different BW groups (group 1: $<5 \mathrm{~kg}$, group 2: $5-10 \mathrm{~kg}$, group 3: $10-25 \mathrm{~kg}$, group 4: 25 $45 \mathrm{~kg}$ and group 5: $>45 \mathrm{~kg}$ ). The Kruskal-Wallis test and post Dunn's test were used for statistical analysis of the electrocardiographic parameters. For all analyses, $\mathrm{P}<0.05$ was considered significant (PROC MIXED, SAS..., 2011).

\section{RESULTS}

The study included 575 females and 425 males with a mean age and standard deviation of $8.53 \pm 3.78$ years, an average weight and standard deviation of $17.07 \pm 13.94 \mathrm{~kg}$ and a mean BSA and standard deviation of $0.64 \pm 0.35 \mathrm{~m}^{2}$. The predominant rhythm was the sinus (554 animals), followed by sinus arrhythmia (302), tachycardia (129) and bradycardia (15). The clinical data and electrocardiographic parameters of the animals are shown in Table 1. The HR obtained by the formula proposed in accordance with the weight was elevated in most groups, when compared to HR obtained by electrocardiogram. 
Table 1. Clinical parameters (mean \pm standard deviation) obtained from 1000 electrocardiographic tracings from the analyzed dogs

\begin{tabular}{llll}
\hline Parameter & Mean \pm SD & Min. & Max. \\
\hline Age in years & $8.53 \pm 3.78$ & 0.00 & 18.00 \\
Weight $(\mathrm{kg})$ & $17.07 \pm 13.94$ & 1.70 & 85.00 \\
Weight $(\mathrm{g})$ & $16.96 \pm 13.95$ & 5.50 & 85.00 \\
BSA (m $\left.{ }^{2}\right)$ & $0.64 \pm 0.35$ & 0.003 & 2.02 \\
HR $(\mathrm{bpm})$ & $126.94 \pm 33.20$ & 51.00 & 160.00 \\
HR=241xBW & $131.67 \pm 28.20$ & 19.961 & 211.06 \\
P (ms) & $0.10 \pm 1.67$ & 0.02 & 0.05 \\
P (mV) & $0.23 \pm 0.09$ & 0.05 & 0.90 \\
PR (ms) & $0.20 \pm 3.57$ & 0.01 & 113.00 \\
QRS (ms) & $0.13 \pm 2.30$ & 0.02 & 0.07 \\
R (mV) & $1.11 \pm 0.50$ & 0.03 & 3.33 \\
QT (ms) & $0.18 \pm 0.03$ & 0.01 & 0.93 \\
T (mV) & $0.25 \pm 0.15$ & 0.03 & 1.24 \\
RR (ms) & $517.69 \pm 147.78$ & 247.00 & 1183.0 \\
Axis $\left({ }^{\circ}\right)$ & $66.43 \pm 25.81$ & -181.00 & 180.00 \\
\hline
\end{tabular}

Within each weight group, no correlation was observed between either HR and BW or HR and BSA. When the correlation test was applied to the joint analysis of BW (pooling all groups), negative correlations were found between $\mathrm{BW}$ and $\mathrm{HR}(\mathrm{r}=-0.1433, \mathrm{P}<0.0001)$ and between HR and BSA $(r=-0.1299, P<0.0001)$, but those correlations were weak. As shown in Table 2, electrocardiographic HR differed between groups, with the smaller dogs showing higher HR. The amplitude of the $\mathrm{P}$ wave differed $(\mathrm{P}=$ 0.01 ) between the dogs, and the animals weighing less than $5 \mathrm{~kg}$ exhibited highest amplitude.

Table 2. Electrocardiographic parameters (mean \pm standard deviation) obtained from electrocardiographic tracings in 1000 dogs according to the BW group

\begin{tabular}{llllll}
\hline $\begin{array}{l}\text { Weight/ } \\
\text { Parameter }\end{array}$ & $<5 \mathrm{~kg}$ & $5-10 \mathrm{~kg}$ & $10-25 \mathrm{~kg}$ & $25-45 \mathrm{~kg}$ & $>45 \mathrm{~kg}$ \\
\hline HR (bpm) & $136.26 \pm 35.93^{\mathrm{a}}$ & $130.76 \pm 30.70^{\mathrm{a}}$ & $122.03 \pm 4.91^{\mathrm{b}}$ & $122.54 \pm 30.84^{\mathrm{b}}$ & $125.04 \pm 28.83^{\mathrm{ab}}$ \\
P (mV) & $0.27 \pm 0.09^{\mathrm{a}}$ & $0.25 \pm 0.08^{\mathrm{bc}}$ & $0.22 \pm 0.10^{\mathrm{d}}$ & $0.20 \pm 0.08^{\mathrm{d}}$ & $0.21 \pm 0.08^{\mathrm{bd}}$ \\
P (ms) & $0.04 \pm 0.02^{\mathrm{a}}$ & $0.04 \pm 0.01^{\mathrm{ac}}$ & $0.04 \pm 0.01^{\mathrm{bc}}$ & $0.05 \pm 0.04^{\mathrm{bc}}$ & $0.06 \pm 0.07^{\mathrm{bc}}$ \\
PR (ms) & $0.08 \pm 0.07^{\mathrm{a}}$ & $0.08 \pm 0.01^{\mathrm{b}}$ & $0.09 \pm 0.09^{\mathrm{cd}}$ & $0.10 \pm 0.03^{\mathrm{de}}$ & $0.10 \pm 0.02^{\mathrm{e}}$ \\
QRS (ms) & $0.05 \pm 0.06^{\mathrm{a}}$ & $0.05 \pm 0.01^{\mathrm{b}}$ & $0.05 \pm 0.05^{\mathrm{cd}}$ & $0.06 \pm 0.06^{\mathrm{d}}$ & $0.06 \pm 0.06^{\text {ed }}$ \\
QT (ms) & $0.16 \pm 0.03^{\mathrm{a}}$ & $0.17 \pm 0.03^{\mathrm{a}}$ & $0.18 \pm 0.02^{\mathrm{b}}$ & $0.19 \pm 0.05^{\mathrm{b}}$ & $0.19 \pm 0.02^{\mathrm{b}}$ \\
R (mV) & $1.07 \pm 0.48$ & $1.15 \pm 0.53$ & $1.11 \pm 0.49$ & $1.10 \pm 0.48$ & $1.14 \pm 0.42$ \\
T (mV) & $0.26 \pm 0.17$ & $0.17 \pm 0.03$ & $0.25 \pm 0.14$ & $0.22 \pm 0.12$ & $0.26 \pm 0.17$ \\
RR (ms) & $489.23 \pm 146.62^{\mathrm{a}}$ & $493.06 \pm 127.22^{\mathrm{a}}$ & $547.70 \pm 153.41^{\mathrm{bc}}$ & $529.55 \pm 160.09^{\mathrm{ac}}$ & $518.80 \pm 141.70^{\mathrm{ac}}$ \\
Axis $\left({ }^{\circ}\right)$ & $63.24 \pm 27.88^{\mathrm{ab}}$ & $62.10 \pm 27.88^{\mathrm{ad}}$ & $68.89 \pm 24.53^{\mathrm{cb}}$ & $69.150 \pm 19.70^{\mathrm{c}}$ & $74.87 \pm 13.54^{\mathrm{c}}$ \\
\hline
\end{tabular}

Kruskal-Wallis test and Dunn's post-test; mV: millivolts; ms: milliseconds; bmp: beats per minute. Different superscript lowercase letters in the same row indicate a significant difference between BW groups $(\mathrm{P}<0.05)$.

For P-wave duration, the group weighing $<5 \mathrm{~kg}$ differed from the other groups, and the animals with weights above $25 \mathrm{~kg}$ exhibited longer durations. For PR interval, there were differences $(\mathrm{P}=0.02)$ between the $<5 \mathrm{~kg}$ group and the other groups and between the group of dogs weighing $5-10 \mathrm{~kg}$ and the other groups. The smaller dogs had shorter PR intervals. The PR interval varied according to HR. There were differences in the duration of the QRS complex $(\mathrm{P}=0.02)$ between the group of dogs weighing less than $5 \mathrm{~kg}$ and the other groups and between the group of dogs weighing $5-10 \mathrm{~kg}$ and the other groups. Dogs with weights above $25 \mathrm{~kg}$ had higher durations of the QRS complex. Regarding the QT interval duration, the group weighing $<5 \mathrm{~kg}$ and the 5 $10 \mathrm{~kg}$ group differed $(\mathrm{P}=0.01)$ from the other groups, with the former two groups exhibiting shorter QT intervals. The QT interval varied according to HR. For the duration of the RR interval, the group of dogs weighing $10-25 \mathrm{~kg}$ differed $(\mathrm{P}=0.03)$ from the less than $5 \mathrm{~kg}$ and 5 $10 \mathrm{~kg}$ groups but not the other groups, which did not differ from one another. 


\section{DISCUSSION}

In this study, large animals had lower HR, as obtained through ECG, than did small animals, which presented higher HR. We observed that HR was inversely proportional to weight in dogs, but the correlation between those variables are weak, demonstrating that weight is not a relevant factor for determining HR. In a previous study evaluating the effect of weight on heart rate variability (HRV), the authors concluded that weight influences the parasympathetic modulation (Magalhães et al., 2015). Thus the activity of the autonomic nervous system should be considered for evaluation of the HR in dogs in a greater magnitude than the weight. The use of swine in human cardiovascular research has progressively increased because of similarities in their heart sizes. In swine, the HR varies according to the $\mathrm{BW}$ and there is an inversely proportional relationship between these variables in this species (Paslawska et al., 2014).

Dogs weighing less than $5 \mathrm{~kg}$ had higher P-wave amplitudes than the other groups. This finding might reflect the use of computerized electrocardiography in the present study. In a previous study, 49 dogs were divided into three weight groups to evaluate and compare electrocardiographic recordings obtained by conventional and computerized methods, and the authors obtained higher P-wave amplitudes by using the computerized method (Gava et al., 2000; Cardoso et al., 2013). We speculate that the P-wave values obtained in this study reflect the use of the computerized technique. The group of dogs weighing less than $5 \mathrm{~kg}$ and $5-10 \mathrm{~kg}$ differed from the other groups in $\mathrm{P}$-wave duration, with shorter $\mathrm{P}$-wave durations. The variability of the P-wave may be associated with body measurements because larger animals have higher values (Cardoso et al., 2013) and increased atrial mass, which are reflected in changes in the P-wave. As the left atrium is generally triggered late in the course of the $\mathrm{P}$ wave, the increased electric strength due to the increased atrial mass lengthens the duration of this wave (Choudhury et al., 2015).

The duration of the PR interval and QRS complex was lower in small dogs. These findings corroborate the findings of Pellegrino et al. (2010), who found a progressive increase in the duration of the QRS complex and a progressive increase in the PR interval in dogs with increasing BW. Thus, small dogs have higher HR values and, consequently, shorter PR intervals. According to Noujaim et al. (2004), the PR interval, in all species, has a greater sensitivity in relation to heart mass than to cardiac length. The group of dogs weighing less than $5 \mathrm{~kg}$ and $5-10 \mathrm{~kg}$ exhibited shorter QT intervals than the dogs of the higher weight groups. In a previous study, higher QT interval values were observed in dogs with higher weights, a pattern attributed to body physiology. Heart rate (and hence QT interval) varies with BW (Oliveira et al., 2014).

In the present study, the group of dogs weighing $10-25 \mathrm{~kg}$ exhibited a longer RR interval than the dogs of the other weight groups. The RR interval varies with the regulation of blood pressure, thermoregulation, respiration, action of the reninangiotensin-aldosterone system and circadian rhythm (Doxey and Boswood, 2004; Lopes et al., 2013). The intrinsic rate of cardiac depolarization is modulated by the sympathetic and parasympathetic nervous systems (Erickson and Detweiler, 2004). The greater the parasympathetic effects, the stronger the fluctuations (Olsen et al., 1999). Thus, the differences in RR interval among the weight groups may be due to differences in the abovementioned factors and as the RR interval reflects the HRV, we observe that in this group the parasympathetic dominance was greater.

In this study, we found that the electrocardiographic variables had an allometric relationship with BW, except for RR. The RR interval is important to analyze the activity of the autonomic nervous system and its effect on HRV that can be analyzed by the Holter exam. A correlation between HR and BW was found, with these two variables presenting an inversely proportional relationship, but this relationship is weak. In addition, these relationships did not occur in all BW groups, demonstrating that the intra-specificity allometric relation between HR and $\mathrm{BW}$ in dogs is not reliable.

\section{CONCLUSIONS}

The results of the study suggest that weight exerts a little influence on HR. The activity of the autonomic nervous system, gender, temperament, metabolic rate and other variables 
can influence HR behavior in a greater magnitude than BW. The HR values obtained by formula $\mathrm{HR}=241 \mathrm{X} \mathrm{BW}^{-0.25}$ are only estimates and yield higher HR values relative to other methods (e.g., ECG), and this formula should not replace conventional methods of measuring HR. There is no allometric relationship between HR and $\mathrm{BW}$ in dogs. This relationship may occur inter-species but in dogs it does not occur intraspecies. In young animals (less than one year old), HR and BSA do not correlate with the weight. The HR expected obtained by logarithmic equation proposed by the "universal law for allometric scaling" differs from that obtained during electrocardiographic tracings. The allometric method provides only an estimate of the HR in dogs, indicating that the formula described in the methodology does not replace the HR measurement in clinical trials.

\section{ACKNOWLEDGEMENTS}

Funding for this research was supported by the Foundation of Research of the State of São-Paulo FAPESP n ${ }^{\circ}$ 2013/10095-9.

\section{REFERENCES}

CARDOSO, M.J.L.; MELUSSI, M.; JUNIOR, A.Z. et al. Computerized ECG in the American Pit Bull Terrier breed dogs. Semina, v.34, p.2341-2348, 2013.

CHOUDHURY, M.; BOYETT, M.R.; MORRIS, G.M.M. Biology of the sinus node and its disease. Arrhythm. Electrophysiol. Rev., v.4, p.28-34, 2015.

DOXEY, S.; BOSWOOD, A. Differences between breeds of $\mathrm{dog}$ in a measure of heart rate variability. Vet. Rec., v.154, p.713-717, 2004.

ERICKSON, H.H.; DETWEILER, D.K. In: REECE, W.O. (Ed.). Physiology of domestic animals. Rio de Janeiro: Guanabara Koogan, 2004. p.999.

FERASIN, L.; AMODO, A.; MURRAY, J.L. Lack of correlation between canine heart rate and body size in veterinary clinical practice. J. Small Anim. Pract., v.51, p.412-418, 2010

GAVA, N.F.; PAULINO, D.; PEREIRA NETO, G.B. et al. Electrocardiography in Beagle dogs. Arq. Bras. Med. Vet. Zootec., v.63, p.317-321, 2000.

HILL, R.C.; SCOTT, K.C. Energy requirements and body surface area of cats and dogs. J. Am. Vet. Med. Assoc., v.225, p.689-694, 2004.
LAMB, A.P.; MEURS, K.M.; HAMLIN, R.L. Correlation of heart rate to body weight in apparently normal dogs. J. Vet. Cardiol., v.12, p.107-110, 2010.

LOPES, P.F.F.; OLIVEIRA, M.I.B.; ANDRÉ, S.M.S. et al. Clinical application of heart rate variability. $J$. Neurosci., v.21, p.600-603, 2013.

MAGALHÃES, A.F.S.; AIRES, L.; MARTINS, C. et al. Heart rate variability, adiposity, and physical activity in prepubescent children. Clin. Auton. Res., v.25, p.169-178, 2015.

NOUJAIM, S.F.; LUCCA, E.; MUNOZ, V. et al. From mouse to whale: a universal scaling relation for the PR interval of the electrocardiogram of mammals. Circulation, v.110, p.2802-2808, 2004.

OLIVEIRA, M.; MUZZI, A.L.; CHEREM, M.; MANTOVANI, M.M. QT interval in healthy dogs: which method of correcting the QT interval in dogs is appropriate for use in small animal clinics? Braz. Vet. Res., v.34, p.469-472, 2014.

OLSEN, L.H.; MOW, T.; KOCH, J.; PEDERSEN, H.D. Heart rate variability in young, clinically healthy Dachshunds: influence of sex, mitral valve prolapse status, sampling period and time of day. J. Vet. Cardiol., v.1, p.1-16, 1999.

PASCHOAL, M.A.; VOLANTI, V.M.; PIRES, C.S.; FERNANDES, F.C. Heart rate variability between different age group. Braz. J. Physiol., v.10, p.413-419, 2006.

PASLAWSKA, U.; NOSZCZYK-NOWAK, A.; PASLAWSKI, R. et al. Normal electrocardiographic and echocardiographic (M-mode and two dimensional) values in Polish Landrace pigs. Acta Vet. Scand., v.56, p.1-13, 2014.

PELLEGRINO, A.; YAMAKI, F.L.; PEREIRA, R.C.P. Standardization of electrocardiographic parameters in Rottweiler, Golden Retriever clinically healthy. Braz. Vet. Res., v.30, p.1083-1088, 2010.

REIS, A.F.; BASTOS, B.G.; MESQUITA, E.T. et al. Parasympathetic dysfunction, heart rate variability and cholinergic stimulation after acute myocardial infarction. Braz. Cardiol. Arch., v.70, p.193-199, 1998.

SAS/Stat user's guide. Version 9.3. Cary, N.C., SAS Institute Inc, 2011.

SOLOVIEV, M.V.; HAMLIN, R.L.; SHELLHAMMER, L.J. et al. Variations in hemodynamic parameters and ECG in healthy, conscious, freely moving telemetrized beagle dogs. Cardiovasc. Toxicol., v.6, p.51-62, 2006. 